Behavior and Social Issues, 26, 156-171 (2017). (C) Virgínia Maria Dalfior Fava \& Laércia Abreu Vasconcelos. Readers of this article may copy it without the copyright owner's permission, if the author and publisher are acknowledged in the copy and the copy is used for educational, not-for-profit purposes. doi: 10.5210/bsi.v.26i0.7825

\title{
BEHAVIOR OF PROGRAMA Bolsa FAMÍlia BENEFICIARIES: A Behavior Analytic Perspective on Fulfillment of EDUCATION AND HEALTH CONDITIONALITIES
}

\author{
Virgínia Maria Dalfior Fava ${ }^{1}$ \\ Ministry of Health, Brazil \\ Laércia Abreu Vasconcelos \\ Universidade de Brasília, Brazil
}

\begin{abstract}
From a behavior analysis perspective, this paper identifies the metacontingencies established by the Programa Bolsa Familia legislation that focus on the fulfillment of education and health requirements by its beneficiaries, called conditionalities. The Programa Bolsa Familia is a conditional cash transfer program, analyzed here as an intervention for an inefficient cultural practice. This cultural practice constitutes interlocked contingencies that hinder school attendance and nutrition of poor and extremely poor children, who turn into adults unprepared for the labor market, perpetuating a cycle of poverty throughout generations. Analysis of the Programa Bolsa Família legislation enabled us to find two main types of metacontingencies: 1) one for behavioral change of members of the beneficiary families; and 2) another for managing the education and health conditionalities, from a chain of behaviors emitted by public servants of three government levels-municipal, state, and federal. This analysis described the variables that may have been maintaining the interlocking behavioral contingencies involving the beneficiaries and their behaviors of accessing health and education services, and the interlocking behavioral contingencies involving the public agents that manage the conditionalities. The study concludes that it's important to consider the influence of other variables, regarding health and education services and labor market, to guarantee selection of a new and more efficient cultural practice and to verify if the theoretical model presented in this study is consistent with reality, by conducting field research or studies with secondary data.
\end{abstract}

KEYWORDS: behavior analysis, evaluation of public policies, metacontingencies, conditional cash transfer program, Programa Bolsa Família

Programa Bolsa Família is a cash transfer program implemented in 2003 by the Brazilian Federal Government, by transferring conditioned cash to poor families. Poor families are identified and enrolled in the Unified Registry for the Federal Government Social Programs (Cadastro Único, in Portuguese). Currently, this is the main strategy to fight poverty in Brazil.

This program consists of three dimensions. The first one refers to the immediate relief from poverty, through the direct income transfer to poor and extremely poor families. The second one refers to the conditionalities, which are the requirements that the beneficiary families must meet in order to remain in the program. And the third dimension relates to the supply of complementary

\footnotetext{
${ }^{1}$ Email contacts: virginiafava@ gmail.com \& laerciavasconcelos@gmail.com
} 
programs and actions, in order to lead families to a scenario of sustained overcoming of social and economic vulnerability (Quinhões \& Fava, in press).

Therefore, Programa Bolsa Família transfers cash to poor families only if members of the family have emitted certain behaviors in areas of education and health. The following behaviors are mandatory in order to receive the cash benefit: $85 \%$ of monthly school attendance for children between six and 15 years old; 75\% of monthly school attendance for youth between 16 and 17 years old; maintaining an updated vaccine schedule for children younger than seven years old; and prenatal and postnatal checkups for pregnant women.

The assumption of cash transfer programs is that healthy and educated children have a higher probability of becoming adults that will be better prepared for the labor market. They will be able to make more money, thus breaking the transmission of poverty throughout generations (Ravallion, 2003). This assumption is based on research that shows that the educational and economic levels of parents have intergenerational effects on education, nutrition and health of their children: as education and income levels of families increase, individuals tend to seek health and education services more often (c.f., Filmer, 2003).

However, behavior-analytic authors question the effectiveness of this kind of programs. Behavior-analytic studies analyzed an American program, Aid to Families with Dependent Children (AFDC), which offers cash benefit conditioned to participation in educational and labor activities (Mattaini \& Magnabosco, 1997; Oppulente \& Mattaini, 1993). These studies showed that this program uses a process of negative reinforcement to maintain behaviors regarding disease prevention and school attendance. Non-emission of these behaviors results in loss of the cash benefit. According to these authors, using aversive components to change behavior is not an effective long-term practice, since it may produce collateral effects, such as aggression, depression, and counter control (Sidman, 1989). Moreover, this new contingency is coercive, produces delayed results, and targets the child's behavior, who is not directly involved in the planned contingency. Thus, one may question whether the behaviors acquired by families per these conditionalities would be maintained after leaving the program, or even if this coercive contingency could reinforce the desired behaviors.

Furthermore, these studies suggest that conditioning a cash benefit to emission of specific behaviors can be inefficient, since they are influenced by distinct variables. Therefore, these activities must be encouraged by an appropriate arrangement of antecedents (situations and events that precede action) and consequents (situations and events that result from action) for the emission of specific behaviors. Both studies agree that establishing effective contingencies is challenging, but this kind of intervention would produce more stable, long-term results, if the expected changes were attained.

A review by The International Bank for Reconstruction and Development-The World Bankon the impact of conditional cash transfer programs in 11 countries (Bangladesh, Cambodia, Chile, Colombia, Ecuador, Honduras, Jamaica, Mexico, Nicaragua, Pakistan, and Turkey), conducted by Fiszbein and Schady (2009), shows evidence of the effects of demanding conditionalities in cash transfer programs. All evaluated programs produced positive results in school enrollment and attendance, with larger effects in countries where the population had lower indexes of income and schooling. Members of beneficiary families also used health services more often, especially those regarding nutrition of children, although changes in vaccination and immunization behaviors were not statistically significant.

Studies that evaluated the impact of Programa Bolsa Família (Amaral \& Monteiro, 2013; Romero \& Hermeto, 2009), conducted with data from the Impact Assessment Survey of Programa 
Bolsa Familia (IABF), collected in 2005 and 2009 (Cedeplar, 2007; MDS, 2010a), also show evidence in favor of conditionalities. Children from beneficiary families had higher school attendance compared to children of poor families with no benefit.

Many behavior-analytic researchers have studied the behavior of individuals in groups and transmission of cultural practices through generations of individuals (Glenn, 1988, 2004; Houmanfar, Rodrigues \& Ward, 2010; Lamal, 1991; Skinner, 1953; Todorov \& Moreira, 2004). It's possible to design intervention strategies to investigate the variables controlling cultural practices and then to change that inefficient practices that result in harmful aggregate products for society, for example, a drastic reduction of non-renewable natural resources, high incidence of preventable diseases, or perpetuation of the cycle of poverty through generations.

Inefficient cultural practices emerge from complex cultural contexts in which the effects of aggregate products of cultural practices are different from the effects of consequences of individual contingencies. In this context, verbal and rule-governed behaviors are indispensable for individuals to experience cultural consequences (Glenn, 1991). This kind of social control can be exerted by the government by rules called laws. Laws are made to promote desirable behavior and eliminate undesirable behavior to society, and they usually don't deal with individual behaviors or with three term contingencies. They are directed to interlocking behavioral contingencies because this ensures a change in cultural practices (Todorov, 2013). The functional relation between a set of interlocked behavioral contingencies that produces an aggregate product and its cultural consequence is called metacontingency (Glenn \& Malott, 2004; Malott \& Glenn, 2006).

Laws that describe the implementation of public policies can result in interventions on cultural practices in order to extinct cultural inefficiencies. Mawhinney (1995) recommends using indicators of cultural practices, such as measures of aggregate product of these practices, for the monitoring of the public policies' results. Emphasis on measures related to aggregate products suggests changing focus from individual behavior to environmental changes produced by interlocking behavioral contingencies. Therefore, success or failure of a practice is defined by changes in a population, not in individuals (Hovell, Wahlgren \& Russos, 1997).

The government and research institutions are usually in charge of monitoring these indicators and planning actions to change them. Behavioral interventions implemented by these institutions may be studied as behavioral technology for the control of human behavior, and are distinguished by the variables that each one manipulates (Skinner, 1961).

Considering that Programa Bolsa Família, as well as other programs of conditional cash transfer, can be considered a behavioral technology for the control of human behavior, the objective of this paper is to analyze contingencies and metacontingencies promoted by this program implementation as a government intervention on an inefficient cultural practice. This cultural practice constitutes interlocked contingencies that hinder school attendance and nutritional state of poor children-who become adults unprepared for the labor market-perpetuating a poverty cycle throughout generations.

\section{Method}

This paper is based on functional analyses to arrange contingencies, macrocontingencies and metacontingencies found in the documents that regulate Programa Bolsa Família, which define the education and health conditionalities for its beneficiaries. This procedure was developed by Todorov, Moreira, Prudêncio and Pereira (2004). 


\section{Objects of Study}

We analyzed articles related to conditionalities of Programa Bolsa Família from the following documents and their updates:

- Law n ${ }^{\text {o }}$ 10.836, from January $9^{\text {th }}$ 2004, which created Programa Bolsa Família among other provisions (Brasil, 2004a);

- Decree $n^{\text {o }}$. 5.209, from September $17^{\text {th }}$ 2004, which regulates Law $n^{\circ} .10 .836$, from January $9^{\text {th }}$ 2004, which created Programa Bolsa Família among other provisions (Brasil, 2004b);

- Decree $n^{\circ} .7 .332$, from October $19^{\text {th }} 2010$, which rephrased and added articles to Decree $\mathrm{n}^{\mathrm{o}} .5 .209$, from September $17^{\text {th }} 2004$, which regulates Law $n^{\circ} .10 .836$, from January $9^{\text {th }}$ 2004, which created Programa Bolsa Família (Brasil, 2010).

- Ordinance GM/MDS $n^{\circ} .321$, from September $29^{\text {th }}$ 2008, which regulates management of conditionalities from the Programa Bolsa Família, and revokes ordinance GM/MDS n ${ }^{\circ}$. 551 , from November $9^{\text {th }} 2005$, among other provisions (MDS, 2008);

- Interministerial Ordinance MEC/MDS $n^{\circ}$. 3.789, from November $17^{\text {th }} 2004$, which established attributions and norms for fulfilling the School Attendance Conditionality of Programa Bolsa Família (MDS, 2004a); and

- Interministerial Ordinance MS/MDS n ${ }^{\circ} .2 .509$, from November $18^{\text {th }} 2004$, which regulates the attributions and norms for offering and monitoring health actions regarding the conditionalities of beneficiaries of Programa Bolsa Família (MDS, 2004b).

- For support in some analyses, we used the following norms:

- Ordinance GM/MDS no .754 , from October $20^{\text {th }}$ 2010, which establishes actions, norms, criteria and procedures to support decentralized management and execution of Programa Bolsa Família in municipalities, among other provisions (MDS, 2010b); and

- Ordinance GM/MDS $n^{\circ} .256$, from March $19^{\text {th }}$ 2010, which establishes actions, norms, criteria and procedures to financially support state management of Programa Bolsa Família, among other provisions. (MDS, 2010c).

\section{Procedure}

We analyzed cultural practices described in the legislation by identifying behaviors emitted by many individuals and verifying the existence of interlocked three-term contingencies that maintain these behaviors. Moreover, we identified or inferred aggregate products that could result from the analyzed cultural practices. We used the following criteria:

- Cultural context: antecedents that enable the existence of cultural practices, analogous to antecedent stimuli from operant contingencies.

- Cultural practices: established behavior patterns for many individuals, involving many members of beneficiary families and public servants.

- Aggregate product: potential product resulting from cultural practices. 
- Cultural consequence: change in a cultural environment that is responsible for selection or extinction of a cultural practice.

- Culturant: recurring interlocking behavioral contingencies having an aggregate product (Glenn \& col., 2016).

- Metacontingency: a contingent relation between 1) recurring interlocking behavioral contingencies having an aggregate product and 2) selecting environmental events or conditions (Glenn \& col., 2016, p.13).

- Culturo-behavioral lineage: the transmission of operant behavior across individual repertoires (Glenn \& col., 2016, p.17).

All the normative documents were analyzed as a set, indicating articles, paragraphs and subsections for each norm, considering that their content is complementary. Decrees $\mathrm{n}^{\circ}$. 5.209 (Brasil, 2004b) and $\mathrm{n}^{\circ} .7 .332$ (Brasil, 2010) are administrative acts that regulate law $\mathrm{n}^{\circ} .10 .836$ (Brasil, 2004a). The ordinances contain instructions regarding application of the law and both decrees. Therefore, we conducted a joint analysis of these documents.

Normative articles, paragraphs and subsections of Programa Bolsa Família were analyzed because they describe the antecedents that define the cultural context, the cultural practices formed by interlocking contingencies involving beneficiaries and public servants responsible for managing the program in all three levels of the Brazilian Federation, and their aggregate products and cultural consequences.

\section{Results and Discussion}

Programa Bolsa Família was analyzed considering that the program is a government intervention on an inefficient cultural practice with the goal of changing behavior. The cultural practice that should be changed with the program results from the behavior of low-income families. To understand the analysis of the program's legislation, we will initially describe the inefficient cultural practice and the metacontingency that involve members of poor families.

This inefficient cultural practice is characterized by individuals that cannot afford basic needs such as appropriate nutrition. Generally, they live in homes with no water drainage and sewer system, and are in need of immediate income. These factors contribute to dissemination of disease in children with nutritional deficits that were not immunized, thus impairing learning in school, leading to school dropout, which is also influenced by a need to enter the labor market prematurely (Chapman, 2006).

The members of poor families don't access enough health and education services because its individual and cultural consequences are delayed and could not maintain these behaviors or practices that promote these behaviors. So, they are not exposed to these reinforcers. A teenager who drops out school after middle school to enter the labor market is not exposed to individual consequences such as to get a better job that requires more study years and pays a higher salary; nor is he exposed to cultural consequences of a cultural practice that the other members of the family participate in, allowing this teenager to stay in school, such as a higher family income.

A cultural environment characterized by a labor market that absorbs underqualified workforce as well as people that accept work for low salaries maintain this practice. Therefore, interlocked contingencies that maintain behavior of poor and extremely poor families, which result in ineffi- 


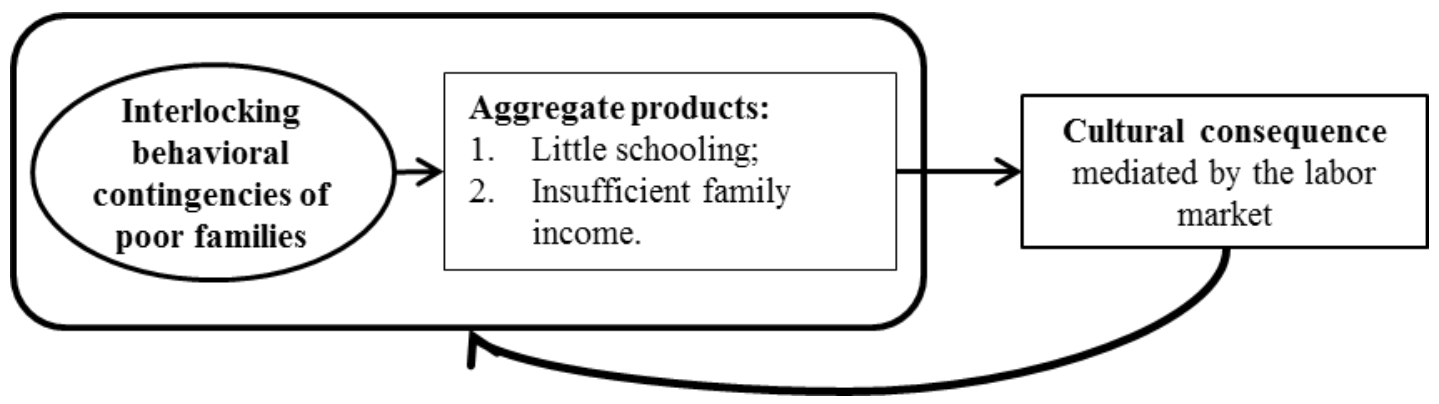

Figure 1. Metacontingency of poor and extremely poor families

cient aggregate products (i.e. little schooling and insufficient family income), are maintained by a cultural environment-the labor market-compose the first metacontingency, shown in Figure 1.

From a joint analysis of the Programa Bolsa Família legislation, we identified the next metacontingencies, which involve the participation of members of the beneficiary families and public servants responsible for managing health and education conditionalities of the program. Next, we will present the two metacontingencies based on this analysis.

\section{Metacontingencies of Members of the Beneficiary Families}

The Programa Bolsa Família legislation describes the eligibility criteria for a family to participate in the program, and establishes the value of cash benefits, considering family composition and program conditionalities. These elements define the antecedent events that evoke a new cultural practice in which members of the beneficiary families participate. The legislation also describes behaviors that must be emitted by family members and the established cultural consequences for a new cultural practice. These elements, as a whole, constitute the metacontingency for the members of beneficiary families of Programa Bolsa Família.

The cultural context is described in Law $n^{\circ}$. 10.836/2004 (Brasil, 2004a), Decree $\mathrm{n}^{\circ}$. 5.209/2004 (Brasil, 2004b), and Ordinance GM/MDS nº. 321/2008 (MDS, 2008). The cultural context includes antecedents that describe the eligibility criteria for a family to benefit from the program. These criteria set limits for family income, which are updated regularly; family composition, such as existence of nursing mothers, pregnant women, children and adolescents; and enrollment of the family in the Unified Registry (Cadastro Único). Thus, only families that meet these criteria can become beneficiaries and participate in the metacontingency.

The antecedents also establish the conditionalities regarding education and health, which must be followed by the members of the beneficiary families to avoid the removal of the cultural consequence. According to Ordinance GM/MDS n. 321/2008 (MDS, 2008), the conditionalities of Programa Bolsa Família are:

- In education: a) for children or adolescents aged between 6 (six) and 15 (fifteen) years old, enrolling in and 85\% (eighty-five percent) of monthly school attendance; and b) for adolescents aged between 16 (sixteen) and 17 (seventeen) years old, enrolling in and 75\% (seventy-five percent) of monthly school attendance;

- In health: a) for pregnant women or nursing mothers, attending prenatal care visits and participating in educational activities on breastfeeding and general caretaking; and b) for 
children younger than 7 (seven) years old, keeping their vaccination up-to-date according to the recommended schedule and monitoring children's growth and development.

Lastly, the legislation defines antecedents that describe the situations in which noncompliance with the conditionalities does not lead to a removal of the cultural consequence: when education or health services cannot be offered due to force majeure or unforeseeable circumstances, or even due to health problems and other reasons recognized by the Programa Bolsa Família management agencies.

Behaviors that members of the beneficiary families should emit are specified in Law $\mathrm{n}^{\circ}$. 10.836/2004 (Brasil, 2004a) and Interministerial Ordinances MEC/MDS nº. 3.789/2004 (MDS, 2004a) and MS/MDS $n^{\circ}$. 2.509/2004 (MDS, 2004b). These behaviors are described by the conditionalities regarding education and health and they compose interlocked behavioral contingencies, which have fulfilling of conditionalities as a more immediate aggregate product, and improvements in health conditions and increase of educational level of family members as delayed aggregate products.

Children and adolescents should attend classes, children up to six-years-old must be vaccinated and pregnant women must attend prenatal care visits. Adults must provide school materials, uniform and transportation for children and adolescents to attend school and take younger children to health centers to get vaccinated; and some pregnant women may need support from other members of the family to attend their prenatal visits. The Programa Bolsa Família legislation does not describe individual contingencies that control the behavior of members of the beneficiary families, nor how they should interlock to guarantee the fulfilling of conditionalities. Members of each family are free to organize in the manner they feel is most adequate, considering other contingencies and metacontingencies surrounding each family, such as the work hours and house chores of adults.

Cultural consequences are broadly described in Law $n^{\circ}$. 10.836/2004 (Brasil, 2004a) and Decree $n^{\circ}$. 5.209/2004 (Brasil, 2004b), and in more detail in Ordinancce GM/MDS n ${ }^{\circ} .321 / 2008$ (MDS, 2008). Consequences for noncompliance with conditionalities involve warnings, and blocking, suspending or cancelling the cash benefit, which are applied successively. Thus, the first occurrence of noncompliance by members of a family, that is, when they do not fulfill at least one of the conditionalities, will be a warning as a consequence. The second occurrence will incur blocking of the benefit for a month. The third occurrence leads to suspension of the benefit for two months. The fourth occurrence cancels the benefit completely. Thus, these aversive consequences are presented gradually, with an increase in magnitude.

Warnings directed at the member responsible for the family, and blocking, suspension or cancelation of the cash benefit, are cultural consequences because they are not contingent of a specific individual behavior. They are, instead, contingent to the culturant that is composed of interlocked behavioral contingencies, which include family members, and their immediate aggregate products, the fulfillment of conditionalities. In order to guarantee the transfer of the cash benefit, all the educational and health conditions must be met. As family members' behaviors are established and transmitted to future generations, a new culturo-behavioral lineage will be constituted, as defined by Glenn and collaborators (2016).

Thus, by establishing a more immediate cultural consequence, through the cash benefit transferred monthly and contingent to a culturant, Programa Bolsa Família seeks to alter cultural 


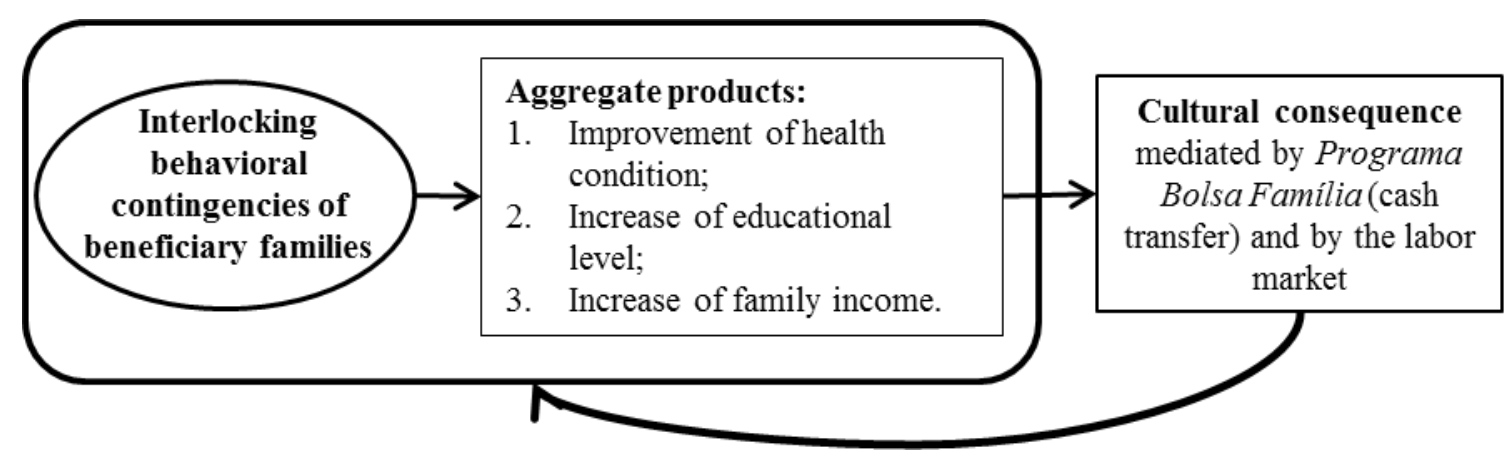

Figure 2. Metacontingencies involving beneficiary families of Programa Bolsa Família

practices of poor and extremely poor families, as shown in Figure 1. Selection of this new practice and the resulting aggregate products is due to a negative reinforcement process; this practice must occur continuously in order to avoid the removal of a reinforcing consequence-the cash benefit. The target aggregate products are improvements in health conditions and increase of family members' educational level, aspects that are considered fundamental to insert these individuals in more advantageous work positions, and consequently increase family income. The metacontingencies described at Programa Bolsa Família legislation may be represented as shown in Figure 2.

These metacontingencies are established for all poor families, so that the aggregate product resulting from the cultural practice of one family will be added to the aggregate products of all the other beneficiary families. In December 2014, there were approximately 14 million beneficiary families, which corresponded to over $25 \%$ of Brazilian families for that year-based on data from the Ministry of Social Development and Fight Against Hunger (Ministério do Desenvolvimento Social e Combate à Fome), and population estimates from the Instituto Brasileiro de Geografia e Estatística (Brazilian Institute of Geography and Statistics). Thus, the program aims to promote improvement of health conditions and increase educational levels and, consequently, increase family income of all the Brazilian population.

As well as the direct effect of the transferred cash benefit on the cultural practice of each family, it is also important to consider that the behaviors of members of a beneficiary family may become antecedent events for other families, that is, for other parents, responsible members, children and youth. In the same manner, the consequences produced by behaviors of each member of a certain family may also function as antecedent stimuli for behaviors of members from other families. Therefore, although the focus of Programa Bolsa Família is the cultural practices of each poor family, the program may induce interweaving of contingencies among individuals from different families. This indirect effect also contributes to the program's objective of increasing Brazilian families' income.

The behaviors that members of the beneficiary families need to emit and the cultural consequences that compose these metacontingencies are clearly specified in the Programa Bolsa Familia legislation. However, the complexity of this legislation, which is based on five different documents, may hinder the ability of beneficiary families of following the established rules. Thus, interventions aimed at informing families about the necessary complementary aspects of these different documents-law, decree and ordinances-should be programmed and periodically applied by public servants of the program in the municipalities. 


\section{Metacontingencies in Managing Conditionalities of Programa Bolsa Família}

According to the Programa Bolsa Família legislation, the management of program's conditionalities should be decentralized through the conjunct efforts of the federated entities. Furthermore, inspection and monitoring should be carried out by the Brazilian Ministries of Health and Education (Ministérios da Educação e da Saúde), while supervision of these processes should be carried out by the Ministry of Social Development and Fight Against Hunger (Ministério do Desenvolvimento Social e Combate à Fome). Legislation also defines the conditions for state governments and municipalities to adhere to the program and institutes the Decentralized Management Index (IGD, in Portuguese). These elements define the cultural context where the new cultural practice should emerge. Public servants responsible for management of conditionalities in the three government levels (municipalities, state governments, and in the three Ministries) are a part of this context. The legislation also describes the behaviors that these public servants must emit and defines some of the cultural consequences for the new cultural practice. Together, these elements compose the metacontingency for managing conditionalities of Programa Bolsa Família. The objective of this metacontigency is to guarantee the functioning of processes related to managing the conditionalities, which are fundamental for the adequate presentation of the cultural consequence of the metacontingencies, in which the members of the beneficiary families of Programa Bolsa Família participate, described above.

The cultural context of this metacontingency includes the legal prescription that the Programa Bolsa Família execution must be carried out in a decentralized manner and the need for state governments and municipalities to adhere to the program. For families in a given municipality to become beneficiaries, a person must be appointed as responsible for managing the program-a state coordinator or municipal manager-and a functioning social control instance. Cultural context also includes the distribution of work by public servants in states and municipalities, as well as in the three Ministries-Social Development and Fight Against Hunger (MDS), Education (MEC) and Health (MS).

The Decentralized Management Index (IGD, in Portuguese) is included in these antecedent events. This index was created by Decree n. 7.332 of 2010 (Brasil, 2010), which also determines the only explicit cultural consequence in the legislation, contingent to the cultural practice established in municipalities and states for managing Programa Bolsa Família. This cultural consequence is the financial resource transferred to states and municipalities. The cash value is determined by the quality of the program management, measured by the integrity and updated information in the Unified Registry (Cadastro Único) and the information provided on monitoring conditionalities. The antecedents are described in the five analyzed documents: Law $\mathrm{n}$. 10.836/2004 (Brasil, 2004a), Decree n. 5.209/2004 (Brasil, 2004b), Ordinance GM/MDS n. 321/2008 (MDS, 2008), Ministerial Ordinance n. MS/MDS 2.509/2004 (MDS, 2004a) and Ministerial Ordinance MEC/MDS n. 3.789/2004 (MDS, 2004b).

The behaviors that should be emitted by public servants are specified in Decree n. 5.209/2004 (Brasil, 2004a), in Ordinance GM/MDS nº 321/2008 (MDS, 2008) Ministerial Ordinances MEC/MDS n. 3.789/2004 (MDS, 2004a) and MS/MDS ${ }^{\circ}$. 2.509/2004 (MDS, 2004b). Legislation describes how public servants, responsible for managing Programa Bolsa Família conditionalities, should proceed to monitor and supervise compliance with the conditionalities by the beneficiary families.

In positions of governance in municipalities, public servants are responsible for collecting, registering, updating, receiving, consolidating and transmitting information concerning 
compliance or violation of conditionalities by beneficiary families, as well as training professionals to carry out these activities and encouraging families to comply with conditionalities. In the state government, public servants are responsible for supporting municipalities in their activities, supporting the health and educational services state network in monitoring conditionalities, and analyzing consolidated information on compliance with conditionalities by beneficiary families.

In the Education and Health Ministries, public servants are responsible for establishing guidelines for monitoring conditionalities by public servants in municipalities and state governments; preparing and maintaining the information registry systems; training state and municipal public servants in their activities; analyzing consolidated data on compliance of conditionalities by beneficiary families; and providing this information to public servants of the MDS. Lastly, MDS public servants supervise and articulate the activities of all the agents involved in managing conditionalities, as well as providing institutional support and updated data from the Unified Registry (Cadastro Único) to public servants of other Ministries; training state and municipal public servants in their responsibilities; and executing consequences for violation of conditionalities, from warnings to cancelling the families' cash benefit.

All these behaviors are organized sequentially, so that some of them are antecedents to others. At the beginning of this sequence, MDS public servants institutionally support MEC and MS public servants so that they acquire the adequate behavioral repertoire to carry out their activities. This support is the antecedent for behaviors of public servants from both Ministries of establishing guidelines and offering training to municipal and state public servants, and develop information registry systems on compliance of conditionalities by the families. MDS public servants also periodically provide data from the Unified Registry (Cadastro Único) to the public servants of the Ministries, which is an antecedent to the behavior of maintaining the information registry system. Training municipal and state public servants by MEC and MS servants and providing the information registry system available with updated data from the Unified Registry (Cadastro Unico) are antecedents to behaviors of supporting health and educational services to manage conditionalities. This is a response class formed by behaviors of collecting, registering, updating, receiving, consolidating and transmitting information concerning compliance or violation of conditionalities by beneficiary families, as well as training professionals to carry out these activities and encouraging families to comply with conditionalities.

The information collected, registered, updated, consolidated, and transmitted through the information registry systems is an antecedent to the behavior of analyzing this consolidated data by state government, MEC and MS public servants. It is also acts as an antecedent for the behavior of public servants from both Ministries of providing this information to MDS public servants. This information is an antecedent for behavior of MDS public servants of executing the consequences directed for the families that violate the conditionalities-warning, blocking, suspension, or cancellation of the cash benefit. This sequence of behaviors may be observed in Figure 3. When a beneficiary family's cash benefit is blocked, suspended or cancelled, the cultural consequence designed by Programa Bolsa Família to the interlocked behavioral contingencies and aggregate products in the metacontingency of members of the beneficiary family [IBCs $\rightarrow$ APs] $\rightarrow$ Cultural Consequence] is removed. This is the link between the two metacontingencies identified in this paper.

The Programa Bolsa Família legislation does not describe these individual contingencies and how they should interlock in order to guarantee occurrence of the aforementioned aggregate products. However, only from the organized execution of all these processes by public servants of the federated entities, including the three Ministries, it will be possible to guarantee that the cultural 
Common antecedent: objective of the PBF of incentivizing families' access to educational and health services, and the importance of adequate monitoring of conditionalities with this purpose.

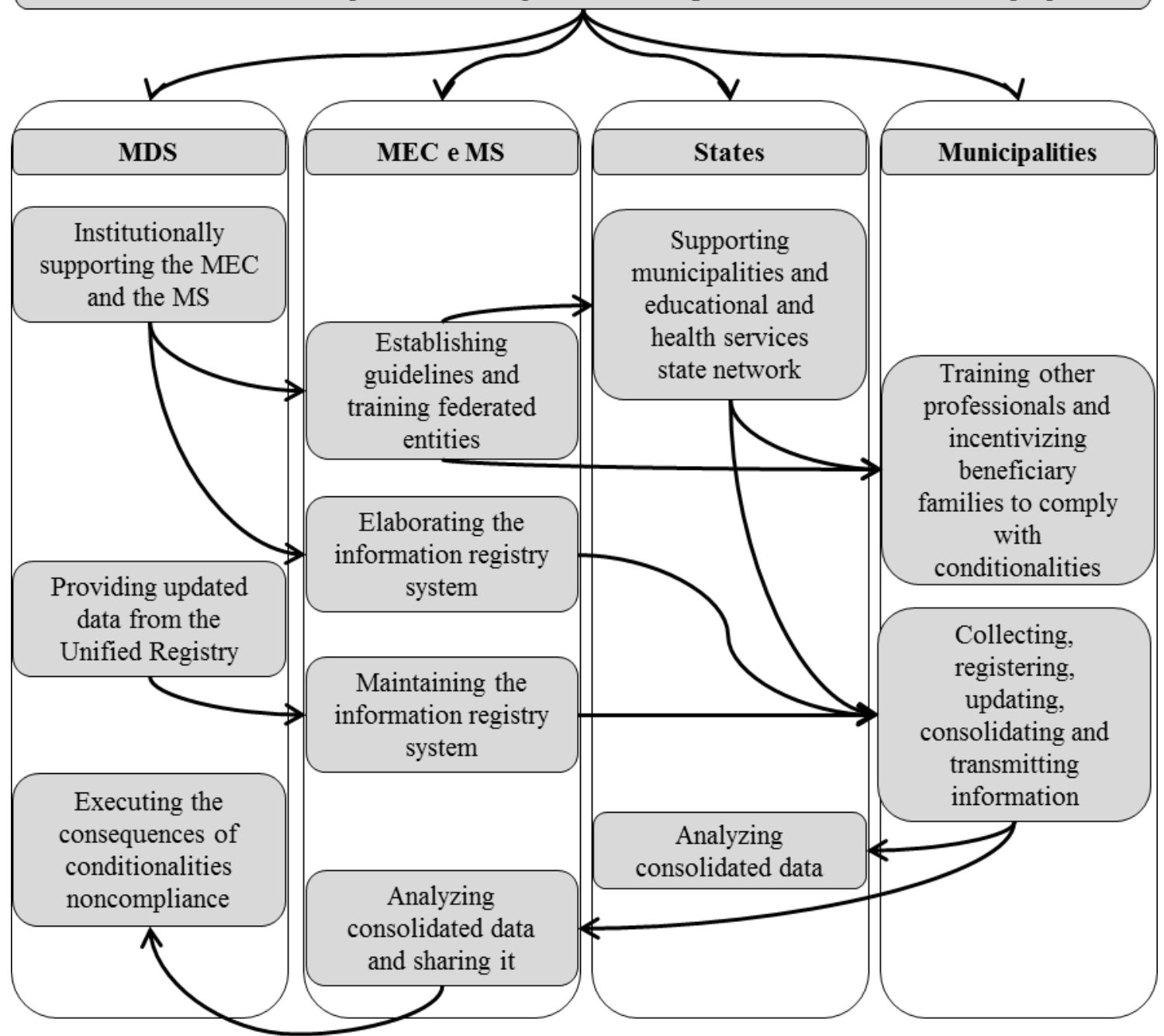

Figure 3. Sequence of behaviors emitted by public servants responsible for management of the conditionalities in Programa Bolsa Família

consequences for cultural practices of beneficiary families will be correctly presented. As these behaviors are established and transmitted, even if there are changes in the composition of the teams in each public repartition, a new cultural-behavioral lineage is constituted, as defined by Glenn et al. (2016), the conditionalities management.

Although the analyzed legislation presents federated entities-municipalities, states and the Federal Government-by setting the competences of the state coordinator and municipal manager, the municipal and state secretaries, and the Ministries as agents, accomplishing these attributions depends on the emission of behaviors of various public servants in interlocked behavioral contingencies prescribed in the Programa Bolsa Família legislation. Each municipality has cultural-behavioral lineages, of which municipal managers and public servants are part: the health agents and teachers that have direct contact with the members of the beneficiary families, the typists that registry data regarding compliance or not of conditionalities, and the analysts that 
monitor records, among others. In each state, there are also interlocked behavioral contingencies with specific aggregate products, in which the state coordinator and the public servants are included. In the Federal Government, there are other interlocked behavioral contingencies, in which the public servants from the three Ministries participate.

As previously mentioned, the program legislation only describes a cultural consequence that is contingent to the interlocked behavioral contingencies, which only public servants from the municipal and state governments are a part of: transferring financial resources of the Decentralized Management Index (IGD, in Portuguese). These financial resources are calculated based on the consolidated data about Programa Bolsa Família in each municipality and state, including monitoring the conditionalities. Thus, payment of the financial resource is a positive reinforcement cultural consequence for the culturant formed by the interlocked behavioral contingencies, which include public servants, and by their aggregate products.

The metacontingencies of managing Programa Bolsa Família conditionalities are formed by a variety of culturo-behavioral lineages of public servants from the municipalities, states and three Ministries. The central aggregate products are: 1) monitoring compliance of conditionalities by the beneficiary families and (2) increasing beneficiary families' access to educational and health services. These aggregate products contribute to the construction of indicators for monitoring the implementation of actions by public servants from the Ministries and the federated entities, and indicators of results of program implementation, forming the complex Programa Bolsa Família.

So, monitoring indicators allow MDS public servants to supervise and articulate activities of the public servants from municipalities, state and from the Ministries of Education and Health, to guarantee management of the conditionalities. Based on indicators of program results, various agents can present other cultural consequences to maintain or alter the managing conditionalities of Programa Bolsa Família. These consequences are presented by congressmen and senators of the Brazilian National Congress, who may propose and approve alterations to law n. 10.836/2004, which guides all the other norms (decrees and ordinances); and by individuals representatives of international organizations whose establish common social and political behavior norms among the member-countries. In Brazil, some international organizations that work with fighting poverty, education, and health are the United Nations (UN) and the United Nations Children's Fund (UNICEF); the United Nations Educational, Scientific and Cultural Organization (UNESCO); the World Health Organization (WHO); and the International Bank for Reconstruction and Development (IBRD). Civil society individuals, who manifest in favor or against maintenance of the program and reelect or not representatives who defend it, also provides cultural consequences (Figure 4). Social participation is encouraged by the Programa Bolsa Família legislation by the instances of social control.

This cultural practice's transmission across generations (see Glenn et al., 2016), may be observed in the continuity of Programa Bolsa Família as a program for transferring conditional income since 2003, even after three municipal elections (2004, 2008 and 2012) and three state elections (2006, 2010 and 2014). Although there is possibility of reelection for a second presidential mandate, as for state governors and mayors, since the 2000 elections (Brasil, 1997), there was change in most mayors. According to the Basic Municipal Information Research (IBGE, 2014), the percentage of reelected mayors was in 2004, 2008 and 2010 of $29 \%, 42 \%$ and $28 \%$ respectively. This allows us to observe the change of most mayors and governors in this period. Even with these changes, the municipalities and states show reoccurrence of relevant interlocked behavioral contingencies for Programa Bolsa Família execution, including management of edu- 


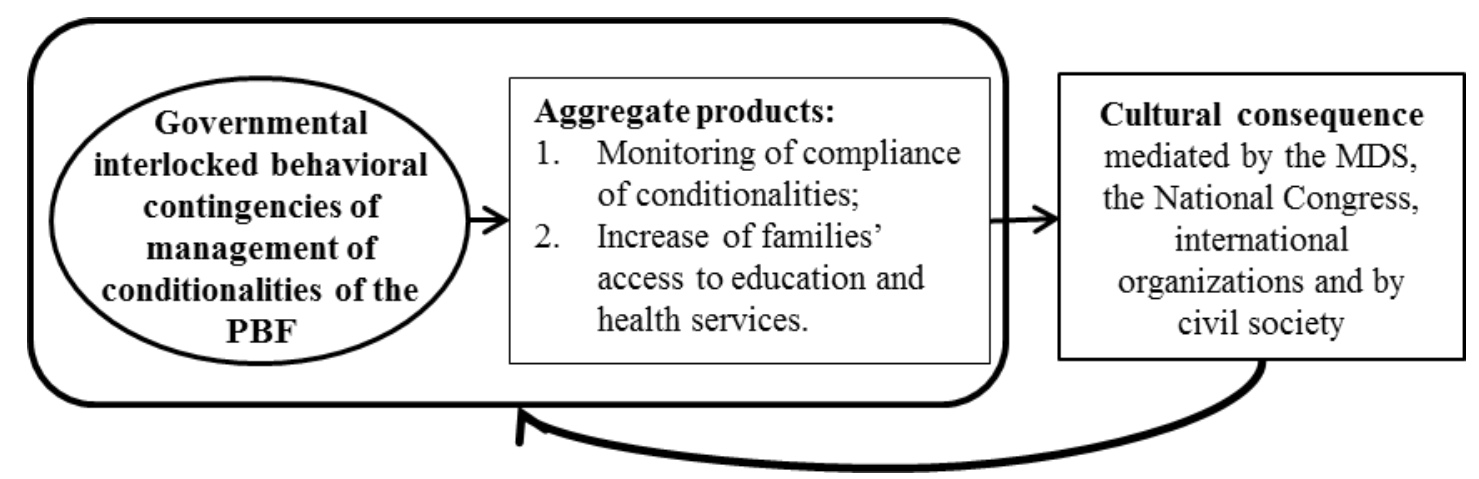

Figure 4. Metacontingency of Managing Conditionalities of Programa Bolsa Família

cational and health conditionalities, and have maintained the necessary aggregate products for its continuity.

More than 6 million beneficiary families and thousands of public servants participate in Programa do Bolsa Família. By using the concept and procedures involved in metacontingency, the main focus of the behavior analyst is not on the number of people involved, but on how their actions participate in interdependent contingencies matrix with environmental events or conditions that selects these interlocking behavioral contingencies and its specific aggregate products. Although it is not a consensus among some behavioral analysts, we defend the usefulness of the concept developed from the 1980s through 245 studies, 154 papers (27 linked to theses and dissertations), 69 master's theses and 22 doctoral dissertations (Vasconcelos \& Lemos, submitted). Cultural interpretations based on macrocontingencies ${ }^{2}$ and metacontingencies terms contribute to the understanding of complex social phenomena and to the planning of large-scale interventions, like Programa Bolsa Família.

If the Program attains the proposed objectives, the children from the beneficiary families will become healthy, educated adults, prepared for insertion in the labor market and able to obtain better salaries, breaking the transmission of poverty across generations (Ravallion, 2003). A new cultural practice will form, composing others new metacontingencies, whose aggregate products will be the improvement of health conditions, an increase of educational levels of the population, and a work force better prepared for the labor market.

This new culturo-behavioral lineage may be selected by cultural environment, substituting the first metacontingency mentioned, with transmission of poverty and extreme poverty conditions. However, if changes in selecting environmental events or conditions do not reinforce these new interlocked behavioral contingencies and its aggregate products, they will last only as long as Programa Bolsa Família, as discussed by Glenn and Malott, (2004b). Other variables must be considered to guarantee the occurrence of these metacontingencies, because of the direct interaction of Programa Bolsa Familia with education and health policies-because of the conditionalities on beneficiaries-as well as its indirect interaction with policies for generating work and income.

For these new metacontingencies, it is necessary to guarantee a cultural consequence mediated also by the labor market, which can be encouraged through public policies aimed at generating

\footnotetext{
${ }^{2}$ Macrocontingency is a relation between 1) operant behavior governed by individual contingencies and/or IBCs governed by metacontingencies and 2) a cumulative effect of social significant (Glenn et al., 2016, p. 19).
} 
jobs and income, for example: policies for increase in minimum wage, labor laws that do not encumber employees and employers, and encouraging legalization of micro and small enterprises. Thus, individuals who participate in this practice will enter the labor market and receive a good salary, increasing their families' incomes or forming new families with higher incomes, breaking the cycle of poverty. In both cases, these families will not need the cash benefit of Programa Bolsa Família anymore.

Besides, as discussed by Mattaini and Magnabosco (1997) and Oppulente and Mattaini (1993), individual behavioral contingencies related to accessing educational and health services need to be guaranteed. Among them are vaccination at public health centers and a welcoming educational system with pedagogical strategies that are interesting for students. These and other variables linked to these services will contribute to the selection of cultural practices of poor families members. Compliance with conditionalities will allow members of beneficiary families to contact these contingencies, but the selection of these cultural practices will depend on reinforcement in these situations.

The analysis of Programa Bolsa Familia legislation allowed to describe the variables that may have been maintaining the interlocking behavioral contingencies involving the beneficiaries and their behaviors of accessing health and education services, and the interlocking behavioral contingencies involving the public agents that manage the conditionalities. However, it's important to find out if the theoretical model presented in this study is consistent with reality, by conducting field research or studies with secondary data (using governmental data, for example).

\section{References}

Amaral, E. F. L., \& Monteiro, V. P. (2013). Avaliação de impacto das condicionalidades de educação do Programa Bolsa Família (2005 e 2009). Revista de Ciências Sociais, 56, 531-570. http://dx.doi.org/10.1590/S001152582013000300003

Brasil (1997). Emenda Constitucional nº 16, de 04 de junho de 1997. Dá nova redação ao $§ 5^{\circ}$ do art. 14, ao caput do art. 28, ao inciso II do art. 29, ao caput do art. 77 e ao art. 82 da Constituição Federal. Retrieved from http://www.planalto.gov.br/ccivil_03/ constituicao/emendas/emc/emc16.htm

Brasil (2004a). Lei no . 10.836, de 09 de janeiro de 2004. Cria o Programa Bolsa Família e dá outras providências. Retrieved from http://www.planalto.gov.br/ccivil_03/_ato2004-2006/2004/lei/110.836.htm

Brasil (2004b). Decreto $n^{\circ}$. 5.209, de 17 de setembro de 2004. Regulamenta a Lei no 10.836, de 09 de janeiro de 2004, que cria o Programa Bolsa Família, e dá outras providências. Retrieved from http://www.planalto.gov.br/ccivil_03/ ato2004-2006/2004/decreto/d5209.htm

Brasil (2010). Decreto $n^{\circ}$. 7.332, de 19 de outubro de 2010, que dá nova redação e acresce artigos ao Decreto $\mathrm{n}^{\circ}$. 5.209, de 17 de setembro de 2004, que regulamenta a Lei $n^{\circ}$. 10.836, de 9 de janeiro de 2004, que cria o Programa Bolsa Família. Retrieved from http://www.planalto.gov.br/ccivil_03/_ato2007-

2010/2010/decreto/d7332.htm

Cedeplar-Centro de Desenvolvimento e Planejamento Regional (2007). Primeiros resultados da análise da linha de base da pesquisa de avaliação de impacto do Programa Bolsa Família. Retrieved from: http://south-south.ipcundp.org/library/primeiros-resultados-da-analise-da-linha-de-base-da-pesquisa-de-avaliacao-de-impacto-toprograma-bolsa-familia.html

Chapman, K. (2006). Using social transfers to scale up equitable access to education and health services. Background paper: Department for International Development-DFID.

Filmer, D. (2003). Determinants of health and education outcomes. Background Note for World Development Report 2004: Making Services Work for Poor People.

Fiszbein, A., \& Schady, N. (2009). Conditional cash transfers: reducing present and future poverty. The World Bank: Washington, D.C.

Glenn, S. S. (1988). Contingencies and metacontingencies: Toward a synthesis of behavior analysis and cultural materialism. The Behavior Analyst, 11, 161-179. http://dx.doi.org/10.1007/BF03392470 


\section{FAVA \& VASCONCELOS}

Glenn, S. S. (1991). Contingencies and metacontingências: Relations among behavioral, cultural, and biological evolution. In P. A. Lamal (Ed.), Behavioral analysis of societies and cultural practices (pp. 39-73). Washington, DC: Hemisphere.

Glenn, S. S. \& Malott, M. E. (2004a). Complexity and selection: implications for organizational change. Behavior and Social Issues, 13, 89-106. http://dx.doi.org/10.5210/bsi.v13i2.378

Glenn, S. S. \& Malott, M. E. (2004b). Behavioral and cultural classifications: Reply to Mattaini. Behavior and Social Issues, 13, 131-133. http://dx.doi.org/10.5210/bsi.v13i2.21

Glenn, S. S., Malott, M. E., Andery, M. A. P. A., Benvenuti, M., Houmanfar, R., Sandaker, I., Todorov, J. C., Tourinho, E. Z., \& Vasconcelos, L. A. (2016). Toward consistent terminology in a behaviorist approach to cultural analysis. Behavior and Social Issues, 25, 11-27. http://dx.doi.org/10.5210/bsi.v25i0.6634

Houmanfar, R., Rodrigues, N. J., \& Ward, T. A. (2010). Emergence and metacontingency: points of contact and departure. Behavior and Social Issues, 19, 78-103. http://dx.doi.org/10.5210/bsi.v19i0.3065

Hovell, M. F., Wahlgren, D. R., \& Russos, S. (1997). Preventive medicine and cultural contingencies: a natural experiment. In P. A. Lamal (ed.), Cultural contingencies: Behavior analytic perspectives on cultural practices. USA: Praeger Publishers.

Instituto Brasileiro de Geografia e Estatística. (2014). Pesquisa de Informações Básicas Municipais. Perfil dos municípios brasileiros 2013. IBGE, Rio de Janeiro, RJ.

Lamal, P. A. (1991). Behavioral analysis of societies and cultural practices. In P. A. Lamal (Orgs), Behavioral analysis of societies and cultural practices (pp. 3-12). Washington, DC: Hemisphere.

Malott, E. M \& Glenn, S. S. (2006). Targets of intervention in cultural and behavior change. Behavior and Social Issues, 15, 31-56. http://dx.doi.org/10.5210/bsi.v15i1.344

Mattaini, M. A., \& Magnabosco, J. L. (1997). Reworking welfare: untangling the web. In P. A. Lamal (Ed.), Cultural contingencies: behavior analytic perspectives on cultural practices (pp. 151-167). Westport, Connecticut: London.

Mawhinney, V. T. (1995). Metabehaviors as discriminative stimuli for planned cultural evolution. Behavior and Social Issues, 5, 35-44. http://dx.doi.org/10.5210/bsi.v5i1.217

Ministério do Desenvolvimento Social e Combate à Fome (2004a). Portaria Interministerial no ${ }^{\circ} .789$, de 17 de novembro de 2004, que estabelece atribuições e normas para o cumprimento da Condicionalidade da Frequência Escolar no Programa Bolsa Família. Retrieved from http://www.mds.gov.br/webarquivos/legislacao/bolsa familia/_doc/ portarias/2004/Portaria\%20Interministerial\%203789\%2017-11-04.pdf

Ministério do Desenvolvimento Social e Combate à Fome (2004b). Portaria Interministerial $\mathrm{n}^{\circ} .2 .509$, de 18 de novembro de 2004, que dispõe sobre as atribuições e normas para a oferta e o monitoramento das ações de saúde relativas às condicionalidades das famílias beneficiárias do Programa Bolsa Família. Retrieved from http://www.mds.gov.br/webarquivos/legislacao/bolsa_familia/_doc/portarias/2004/Portaria\%20Interministerial $\% 202509 \% 2018-11-04 . p d f$

Ministério do Desenvolvimento Social e Combate à Fome (2008). Portaria GM/MDS nº. 321, de 29 de setembro de 2008. Regulamenta a gestão de condicionalidades do Programa Bolsa Família, revoga a portaria GM/MDS $\mathrm{n}^{\circ}$ 551 , de 9 de novembro de 2005, e dá outras providências. Retrieved from http://www.mds.gov.br/webarquivos/legislacao/assistencia_social/portarias/2008/Portaria\%20no\%20321$\% 20 \mathrm{de} \% 2029 \% 20 \mathrm{de} \% 20$ setembro\%20de\% 202008.pdf

Ministério do Desenvolvimento Social e Combate à Fome (2010a). Síntese do primeiro relatório contendo os principais resultados da pesquisa de avaliação de impacto do Bolsa Família-segunda rodada-AIBF II. Nota técnica. Retrieved from file:///C:/Users/virginia.fava/Downloads/NT_110_2010_Sintese_AIBF_2a_rodada_educa\%C3\%A7\%C3\%A3o $\% 20 \mathrm{e} \% 20 \mathrm{sa} \% \mathrm{C} 3 \%$ BAde.pdf

Ministério do Desenvolvimento Social e Combate à Fome (2010b). Portaria GM/MDS nº 754, de 20 de outubro de 2010. Estabelece ações, normas, critérios e procedimentos para o apoio à gestão e execução descentralizadas do Programa Bolsa Família, no âmbito dos municípios, e dá outras providências. Retrieved from http://www.mds.gov.br/webarquivos/legislacao/bolsa familia/portarias/2010/Portaria\%20n\%C2\%BA\%207542010.pdf

Ministério do Desenvolvimento Social e Combate à Fome (2010c). Portaria GM/MDS nº. 256, de 19 de março de 2010. Estabelece normas, critérios e procedimentos para o apoio financeiro à gestão estadual do Programa Bolsa Família e dá outras providências. Retrieved from http://www.mds.gov.br/webarquivos/legislacao/bolsa_familia/portarias/ 2010/Portarian256_2010.pdf 


\section{PROGRAMA BOLSA FAMILIA}

Opulente, M., \& Mattaini, M. A. (1993). Toward welfare that works. Behavior and Social Issues, 3, 17-34. http://dx.doi.org/10.5210/bsi.v3i1.197

Quinhões, T. A. T., \& Fava, V. M. D. (in press). Social inclusion and facing poverty in Brazil: the experience of Bolsa Família Program and the Brasil Sem Miséria Plan. Policy Research Briefs, International Policy Centre for Inclusive Growth.

Ravallion, M. (2003). Targeted transfers in poor countries: revisiting the trade-offs and policy options. World Bank, Development Economics Research Group, Washington, D. C. Retrieved from http://documents.worldbank.org/curated/pt/865121468762562956/ Targeted-transfers-in-poor-countriesrevisiting-the-trade-offs-and-policy-options

Romero, J. A. R. \& Hermeto, A. M. (2009, dezembro). Avaliação de impacto do Programa Bolsa Família sobre indicadores educacionais: Uma abordagem de regressão descontínua. Em Anais do Encontro Nacional de Economia, ANPEC, Foz do Iguaçu/PR.

Sidman, M. (1989). Coercion and its fallout. Boston: Authors Cooperative.

Skinner, B. F. (1953). Science and human behavior. New York: McMillan.

Skinner, B. F. (1961). The design of cultures. Daedalus, 90, 534-546.

Todorov, J. C. (2013). Conservation and transformation of cultural practices through contingencies and metacontingencies. Behavior and Social Issues, 22, 64-73. http://dx.doi.org/10.5210/bsi.v22i0.4812

Todorov, J. C., \& Moreira, M. (2004). Análise experimental do comportamento e sociedade: Um novo foco de estudo. Psicologia: Reflexão e Crítica, 17, 25-29. http://dx.doi.org/10.1590/S0102-79722004000100005

Todorov, J.C.; Moreira, M.; Prudêncio, M.R.A. \& Pereira, G.C.C. (2004). O Estatuto da Criança e do Adolescente como metacontingência. Em M.Z.S.Brandão; F.C.S.Conte; F.S.Brandão; Y.K.Ingberman; V.L.M.Silva; S.M.Oliani (Orgs.). Sobre Comportamento e Cognição: contingências e metacontingências, contextos sócioverbais e o comportamento do terapeuta, pp. 44-51. Santo André: ESETec.

Vasconcelos, L. A., \& Lemos, R. F. (Submitted). Selection by consequences: cultural contingencies in the theoretical system of B. F. Skinner with the conjugation of observation, experimentation and interpretation. 